\title{
Alternative Definitions of the Budget Deficit and its Impact on the Sustainability of Fiscal Policy in South Africa
}

Davina Jacobs ${ }^{1}$,
Niek Schoeman
Jan van Heerden

\section{ABStRact}

This paper investigates the usefulness of different definitions of the budget deficit and their impact on fiscal sustainability. The analysis shows that a number of alternative definitions of the budget deficit are useful, some even extremely useful, for analyzing the impact of fiscal policies. The choice among the alternatives depends mainly on the purpose for which it is intended. However, despite the usefulness of the different definitions of the deficit, their order of magnitude in South Africa differs only marginally from that of the operational deficit. In our analysis of fiscal sustainability, the full range of possibilities have been accommodated in the different scenarios with the operational deficit. With a finite time horizon medium term current fiscal policy can be said to be sustainable or intertemporaly consistent, if it is able to achieve a given target level of the debt/GDP ratio. Unlike the infinite time horizon case, this target level might be nonzero. In this paper the latter case has been investigated. Three possible alternatives were tested and the results indicate that there is little room for fiscal maneuverability in South Africa without jeopardizing fiscal discipline policies. In the longer term, different definitions of the budget balance do not change this reality.

JEL Classification Numbers:

$\mathrm{H} 62$

Keywords:

Budget deficit; fiscal indicators; fiscal stance

\footnotetext{
1 Economist, IMF

${ }^{2}$ Professors, Department of Economics, University of Pretoria
} 


\section{INTRODUCTION}

Fiscal deficits were at the forefront of macroeconomic adjustment policies in the 1980s and 1990s, in both developing and industrial countries. They were originally blamed in large part for the assortment of ills that had beset developing countries at that time: over indebtedness, high inflation, and poor investment and growth performance. In the 1990s, fiscal deficits also occupied center stage in the massive reform programs which were initiated in the BRO countries and many other developing countries on all continents (Easterly and Schmidt-Hebbel 1994: 15).

The successes and failures of fiscal adjustment raise many issues. Not the least of these is how to define and measure fiscal adjustment. What are the most meaningful measures of public sector deficits? How should one assess fiscal stance, public sector solvency, and sustainability of deficits? The budget deficit is therefore often subjected to intense interest and scrutiny. Unless interpreted with caution however, the conventionally defined budget deficit could give rise to misleading conclusions of fiscalpolicy stance and possible erroneous policy prescriptions (Abedian and Biggs 1998: 185).

During the last few years policy makers in South Africa placed more emphasis on limiting the role of government in the economy and lowering the budget deficit as two of the policy goals of the Growth, Equity and Redistribution strategy as adopted in 1996 (see GEAR 1996: 7-9). The development in 1997 of a Medium Term Expenditure Framework (MTEF) in South Africa once again placed emphasis on the use of the conventional budget deficit - seeing that it was used as a primary policy goal. This led to the question: is the conventional budget balance the correct indicator to measure the stance of fiscal policy in South Africa? As noted in recent literature, several other fiscal indicators are proposed as alternatives to the conventional budget balance and are already used with success by international organizations such as the IMF and the OECD. This study, focusing on South Africa, aims to explore the possible use of alternative fiscal indicators to monitor and evaluate the sustainability of fiscal policy in South Africa.

Critical analysis of the conventional budget balance shows that it is not an ideal measurement instrument for the situation in South Africa. It should be mentioned that several aspects such as a comprehensive balance sheet for government and concepts like the net worth of government were not researched in this paper. At the time of the study, certain problems with the availability of data on valuation of (non-financial) government assets as well as verification of certain government liabilities were experienced. ${ }^{3}$ These data limitations will only be removed if comprehensive reforms in fiscal accounting in South Africa are implemented. Certain alternative budget balance norms - the so-called domestic and external budget balances - were also not fully developed.

\footnotetext{
3 South Africa has yet to move to full accrual accounting in the public sector.
} 


\section{ALTERNATIVE DEFINITIONS OF THE BUDGET DEFICIT}

The term "budget deficit or budget balance" appears regularly in news articles, in government policy documents - usually with the warning that it is very undesirable (Eisner 1997: v). The blame for several economic ills, such as high inflation and the discouragement of private investment, is sometimes placed on (usually too high) budget deficits (see among other Eisner 1989: 73 - 79). Concrete proof for all these assumptions of "guilt" is seldom provided and little attention is paid to the "objective" measurement and interpretation of the budget deficit. ${ }^{4}$

The measurement of budget balances also raises a host of conceptual and practical issues, which are compounded by the lack of uniformity in usage among countries. For instance, the conventional budget balance can be measured on a cash basis or an accrual (or payment order) basis. In the first case, the balance equals the difference between total cash flow expenditure and fiscal revenue. In the second case, the balance reflects accrued income and spending flows, regardless of whether they involve cash payments or not. Accumulation of arrears on payments or revenue is reflected by higher balances when measured on an accrual basis compared with a cash-based measure (Agénor and Montiel 1999: 141).

According to economic literature and practices by institutions such as the World Bank and the IMF, a couple of different ways to measure the conventional budget balance exists. The most commonly accepted measure used by governments world-wide to define the conventional budget balance is the resources utilized by the government in a fiscal year that need to be financed after revenues were deducted from the expenditure. According to Tanzi in Blejer and Cheasty (1993: 13) the conventional balance can therefore usually be defined as the difference between current revenues and current expenditure of government. It thus reflects the financing gap that needs to be closed by way of net lending, including lending from the central bank.

The World Bank defines the conventional budget balance as the difference between expenditure items such as salaries and wages, expenditure on goods and services including capital expenditure, interest on public debt, transfers and subsidies, and revenue items including taxes, user charges, grants received, profits of non-financial public enterprises and sale of assets (Blejer and Cheasty 1990: 2-3).

The IMF stated in its 1986 Manual on Government Finance Statistics that the budget balance equals the following fiscal balance:

\footnotetext{
${ }^{4}$ For a detailed description of the different schools of thought on the importance of the budget deficit, see Jacobs (2000: 16 - 53).
} 
Fiscal balance $=\{($ revenue + grants $)-$ (expenditure on goods and services + transfers $)$ - (lending - repayments)\}.

The conventional budget balance on a cash basis is defined as the difference between total government expenditure (including interest payments on public debt but excluding any amortization payments) and total cash receipts (including taxes and non-tax revenues plus grants, without loans. It does not, however, provide a direct measure of monetary expansion nor of the pressure as a result of increased demand for financial instruments in the short-term markets. This definition of a conventional budget balance is therefore independent from the maturity schedules of outstanding domestic public debt and the reasons related to monetary policy. But it also poses a problem: public debt management and open market transactions can, in the end, greatly influence the size of the budget balance.

The conventional budget balance was originally developed in an effort to provide a measure of the government's contribution to aggregate demand in the economy and the lack of equilibrium on the current account of the balance of payments, or to measure the crowding out of the private sector in the financial markets. ${ }^{5}$ Another definition of the conventional budget balance could be the measurement of the extent to which government expenditures (for policy purposes) exceed government revenues without incurring new liabilities, as proposed by Leviathan in Blejer and Cheasty (1993: 259).

Heller, Haas and Mansur (1986: 18) described the conventional measurement of the balance as a reflection of the current cash flow position of government - calculated by only using the cash receipts and cash expenditure in a given time period. Expenditure includes interest payments but excludes repayments of public debt.

Alternative indicators to measure the different interpretations of fiscal policy have increasingly been used by a large group of countries and international organizations such as the $\mathrm{IMF}^{6}$, the World Bank, the OECD and the European Union (EU). Countries use different definitions of the budget balance mainly because of convention, relationships with other levels of government and the structure of their budgets (United States General Accounting Office 1996: 25 - 26). Mexico and the UK further analyze the public sector borrowing requirement; while Australia, Canada and Germany focus on central or federal government activities; with Japan following a much narrower approach by considering the central government only in part.

In summary, the conventional budget balance can be regarded as the resources needed during a fiscal year after government income has been deducted from total

\footnotetext{
5 This broader description of the conventional deficit is also measured on a cash basis (Robinson and Stella in Blejer and Cheasty 1993: 237 -238).

6 The IMF mainly uses the conventional ("overall") budget balance, especially in the context of an IMF program.
} 
expenditure. The latter expenditure total includes interest payments but not any amortization of public debt.

Thus, the choice of a budget balance is mainly focused on the interpretation and management of fiscal policy. There is no single superior measure of the budget balance - rather a set of different budget balances measurements, each applicable to specific conditions.

Although numerous different permutations of budget balances and other fiscal indicators exist (see table 1 below), only fifteen of them could be quantified for South Africa, given the lack of appropriate data. It includes the current balance (measuring government savings); the primary balance (which excludes interest payments); the deficit excluding transfers, etc. These definitions are supplemented by the cyclically adjusted and the cyclically neutral balances, which allow for the effects of cyclical variations in the business cycle, when measuring the effect of fiscal policy on the economy (the cyclical neutral balance only adjusts on the revenue side of the budget). Other indicators include the real and operational balance (adjusted for inflation); weighted balances (where the choice of weights depends on the relative importance according to policy variations - this is useful when analyzing policy outcomes versus policy goals); and the full employment balance. 


\section{Table 1 Alternative definitions of the budget deficit}

\begin{tabular}{|c|c|c|}
\hline & Fiscal indicator & Definition \\
\hline 1 & Conventional budget balance & $=$ Expenditure - Income \\
\hline 2 & Total budget balance without grants & $=$ Conventional balance $(1)$ - grants \\
\hline 3 & External budget balance & $=$ govt exp. - receipts (externally financed) \\
\hline 4 & Domestic budget balance & $=$ total balance - external balance \\
\hline 5 & Primary budget balance & $=$ total balance - interest payments \\
\hline 6 & Operational budget balance & $=$ primary balance + real interest payments) \\
\hline 7 & Current budget balance & $=$ current revenue - current expenditure \\
\hline 8 & Consolidated budget balance & $\begin{array}{l}=\text { Central }+ \text { decentralized government } \\
\text { balances }\end{array}$ \\
\hline 9 & Cyclically neutral budget balance & $\begin{array}{l}=\text { Expenditures }- \text { cyclically adjusted } \\
\text { revenue }\end{array}$ \\
\hline 10 & Cyclically adj. budget balance & $=$ total balance - cyclically neutral balance \\
\hline 11 & Benchmark budget balance & $\begin{array}{l}=\text { normative year balance (as pre- } \\
\text { determined) }\end{array}$ \\
\hline 12 & Structural budget balance & $\begin{array}{l}=\text { cyclical effect of budget + benchmark } \\
\text { balance }\end{array}$ \\
\hline 13 & Full employment budget balance & $=$ full empl. exp. - full empl. revenue \\
\hline 14 & Liquidity budget balance & $=$ total balance - net loans \\
\hline 15 & Weighted budget balance & $\begin{array}{l}=\text { weights allocated according to the } \\
\text { importance of operational variables }\end{array}$ \\
\hline
\end{tabular}

Each definition highlights a particular aspect of fiscal exposure and can serve a valuable purpose from the viewpoint of investors and policy analysts. The idea is to use a set of different definitions of the deficit to get the full picture with regard to the fiscal stance of the country. The determining factor is whether fiscal policy is sustainable in the longer term.

A comparison between the different definitions of the budget deficit indicated that they do not differ that much in magnitude. The variations range from a surplus of two per cent of GDP to a deficit of five per cent of GDP. Excluding the differentiating variables, they all rely heavily on the level and size of economic growth, interest rates and inflation.

In fiscal analysis it is common practice to use the operational deficit to measure fiscal sustainability, which seems to be a good choice especially in view of the fact that the other definitions only differ marginally in terms of their relationships to GDP). In the next section an attempt has been made to measure fiscal sustainability, using the operational deficit with different scenarios covering the full range of deviations from other definitions (two per cent surplus to a five per cent deficit).

\section{MEASURING THE SUSTAINABILITY OF FISCAL POLICIES}


The sustainability of fiscal policy given different definitions of the budget deficit is measured in terms of standard theory on the intertemporal budget constraint (Uctum and Wickens: 3). The government's intertemporal budget constraint can be written in nominal terms as

$$
\mathrm{G}_{\mathrm{t}}-\mathrm{T}_{\mathrm{t}}+\mathrm{iB} \mathrm{B}_{\mathrm{t}-1}=\Delta \mathrm{B}_{\mathrm{t}}+\Delta \mathrm{M}_{\mathrm{t}}=-\mathrm{S}_{\mathrm{t}}
$$

where $\mathrm{G}$ is government spending on goods and services and transfers, $\mathrm{T}$ is government revenue, $B$ is the value of the public debt outstanding, at period $t^{7}, i$ is the interest rate on government debt, $\mathrm{M}=$ monetary base and $\mathrm{S}=$ total budget surplus. The debt in year $t$ is equal to the difference between spending and revenue for year $t$, plus the sum of the outstanding debt and the interest cost thereon. Note that $\mathrm{G}$ does not include interest payments on government debt: these are included in the term $\mathrm{i}_{\mathrm{t}} \mathrm{B}_{\mathrm{t}-1}$. Expressing (1) in terms of ratios to nominal GDP gives:

$$
g_{t}-\tau_{t}+\left(i-\Pi_{t}-\eta_{t}\right) b_{t-1}=\Delta b_{t}+\Delta m_{t}+\left(\Pi_{t}+\eta_{t}\right) m_{t-1}=-s_{t}
$$

where the lower-case letters $\mathrm{g}, \tau, \mathrm{b}, \mathrm{m}$ and $\mathrm{s}$ denote the ratio of the corresponding upper-case variables to nominal GDP, $\Pi_{t}=\left(P_{t}-P_{t-1}\right) / P_{t-1}$ and $\eta_{t}=\left(Y_{t}-Y_{t-1}\right) / Y_{t-1}$, with $P$ and $Y$ standing for the price level and real GDP respectively. Equation (2) says that new bond issues, money-base creation and seignorage finance the interest-inclusive government deficit. Equation (2) can be rewritten as:

$$
d_{t}+\rho_{t} b_{t-1}=\Delta b_{t}
$$

where $d_{t}=g_{t}-\tau_{t}-\Delta m_{t}-\left(\Pi_{t}+\eta_{t}\right) m_{t-1}$ is the primary government deficit expressed as a proportion of nominal GDP and $\rho_{t}=\mathrm{i}_{\mathrm{t}}-\Pi_{\mathrm{t}}+\eta_{\mathrm{t}}$ is the real ex post interest rate adjusted for real output growth. Equation (3) is an identity, which holds ex post in time t. Looking forward, the identity can only hold in ex ante terms. Thus, in period $t+1$,

$$
b_{t}=E_{t}\left[\left(1+\rho_{t+1}\right)^{-1}\left(b_{t+1}-d_{t+1}\right)\right]
$$

where $b_{t}$ is known in period $t$, and for the one period budget constraint to hold in expectational terms, must equal the expected discounted net debt/GDP ratio in period $t+1$, conditional on information at time $t$. In order for fiscal policy to be sustainable for one period in the future, equation (4) must hold.

The corresponding expression for $\mathrm{n}$ periods ahead is obtained by solving forwards and successively substituting out the future compound discounted debt-GDP ratio to give the $n$-period intertemporal budget constraint:

\footnotetext{
${ }^{7}$ Debt $=$ net market value of debt $=$ gross debt - financial assets.
} 


$$
b_{t}=E_{t} \delta_{t, n} b_{t+n}-E \sum_{i=1}^{n} \delta_{t, i} d_{t+i}
$$

where

$$
\delta_{t, n}=\prod_{s=1}^{n}\left(1+\rho_{t+s}\right)^{-1}
$$

is the time-varying real discount factor $n$ periods ahead, adjusted for real GDP growth rate, $r_{t}$ defined as

$$
r_{\mathrm{t}}=\prod_{s=1}^{t} \frac{1}{\left(1+i_{s}\right)}
$$

In other words, the present stock of debt is equal to the sum of the present value of future primary surpluses plus the present value of the stock of debt in year "n".

From an intertemporal budget constraint point of view the government would be solvent if the present stock of government debt were equal to the present value of all future primary surpluses. Thus, a necessary condition for sustainability is that as $n$ moves to infinity, the discounted value of the expected debt/GDP ratio converges to zero. This is also known as the transversality condition, meaning that no new debt is issued to meet interest payments.

In the paper Equation (5) has been used to demonstrate what influence of different future values of $d_{t}$ will have on the current value of debt, $b_{t}$. It is not feasible, however, to keep $\delta_{t}$ constant in a partial type of analysis, since it might change when $d_{t}$ changes over time.

A simple OLS regression was performed on data from five countries with low deficit/GDP ratios and five countries with relatively high deficit/GDP ratios between 1990 and 1999. The former countries included Norway, USA, Korea, Ireland, and Denmark, while the latter group countries comprised Italy, Belgium, UK, France and Spain. It was found that the long-term interest rates in these countries could be explained by the $\mathrm{CPIs}$, and also by the deficit/gdp ratio in the case of high budget deficits. The following two results were found for the long-term interest rates, with all t-values highly significant:

$$
\begin{array}{ll}
\text { In high deficit countries: } & \mathrm{LR}=3.318+1.092^{\star} \mathrm{CPI}+0.333^{\star} \mathrm{DEF} / \mathrm{GDP} \\
\text { In low deficit countries: } & \mathrm{LR}=6.951+0.829^{\star} \mathrm{CPI}
\end{array}
$$

In the various scenarios tested below, these relationships were taken into account. We did not guess the long-term interest rates, but made them dependent on the chosen $\mathrm{CPIs}$ and deficit/gdp ratios. The values of the total debt over time in the scenarios are calculated from starting values of the debt, and the chosen deficit/gdp ratios. The chosen values in the various scenarios are therefore $d_{t}, C P I$, and $\eta_{t}$. All other columns in the tables are calculated from these. 
Scenario 1 (see Table 2) represents a high deficit case where the deficit/GDP ratio is set at the 5 per cent level over the 10-year horizon (2000 to 2010). The Table shows that such a high deficit clearly does not portray fiscal discipline in the South African case. The value of $b_{t}$ (the discounted value of accrued deficits and debt over the 10 year horizon) is 76.5 which is clearly not sustainable given the historic 1999 debt/GDP ratio of 48,2 per cent. A main problem here is the structural constraints in the production capacity of the South African economy which cause the economic growth rate to be restricted to a 2,5-3.0 per cent growth limit. Furthermore, the inflation rate increases to the 8 per cent level with the long-term interest rates at approximately 14 per cent. Different definitions of the deficit are all derived from the elements of the conventional definition used in the discounting exercise. Therefore, although it is useful to analyze the real impact of fiscal policy in the shorter term, the long term implications thereof have to be considered given the scenario of an increase of approximately two times the base figure over ten years.

Scenario 2 (see Table 3 ) represents a combination of parameters which are highly favourable from the view of fiscal discipline. In this case the definition has been changed to reflect a deficit/GDP ratio of -1 per cent (in other words a budget surplus). In this case the long-term interest rates decrease to 11.9 per cent with the inflation rate lower at 6 per cent and growth at 3.5 per cent. The discounted value of $b_{t}$ is lower at 23.1 per cent compared to the 1999 value of 48,2 percent. This scenario clearly illustrates that given the structural constraints within the South African economy, a balanced budget will bring the debt/GDP ratio down to levels, which are comparable to those of the most successful economies in the world. Whether it is realistic to expect that this is the most preferable level of debt given the enormous socioeconomic demands in this country is debatable.

In scenario 3 (Table 4) a deficit/GDP ratio of 1.5 percent was chosen. In this case the interest rates were not different from the surplus scenario and the inflation rate as well as the economic growth rate remained unchanged. Over the ten-year period the debt/GDP ratio declines to 46,2 percent, which is marginally lower than the ratio at the beginning of the period. Thus, should the current debt/GDP ratio be regarded as acceptable in terms of the definition of fiscal discipline, it is only sustainable should the deficit/GDP ratio not exceed the 1,5 percent level. That would mean that fiscal discipline will have to be much more strict than what it currently is with the expected deficit/GDP ratio in the vicinity of 2,5 percent.

\section{Conclusion}

Our conclusion is that the variety of information available in the different alternative fiscal indicators is useful, some even extremely useful. The development of alternative budget balances or fiscal indicators can therefore contribute to more effective fiscal policy and fiscal analysis in general. The choice between the alternatives depends mainly on the purpose it is intended for. However the longer-term implications of fiscal 
expansion have to be viewed against the background of the impact that the conventional deficit has on fiscal sustainability.

It is proposed that alternative definitions outlined in this study be used for proper fiscal analysis. For example, the cyclical adjusted indicator can be extremely useful in this context given the transitional phases through which the South African economy is moving and its impact on government responsibility to intervene and to rectify imbalances at various levels. However, other definitions do not provide any leeway for fiscal expansion from the view of fiscal sustainability. Within a finite time horizon of 10 years, the preferred scenario is one where the def/GDP ratio is lower than two per cent. The capacity constraints on the supply side of the economy are of such a nature that very little fiscal maneuverability is possible. 


\section{Table 2}

\section{Scenario 1}

\begin{tabular}{|c|c|c|c|c|c|c|c|c|c|c|c|c|c|c|}
\hline Year & GDP & $\begin{array}{l}\text { Def/ } \\
\text { GDP }\end{array}$ & $\begin{array}{l}\text { Debt/ } \\
\text { GDP }\end{array}$ & LT Rate & CPI & nu & rho & 1+rho & delta & debt & Delta*b & Delta*d & $\begin{array}{c}\text { Sum- } \\
\text { delta*d }\end{array}$ & bt \\
\hline 1999 & 795575 & 5 & 47.47 & 12.035 & 6.5 & 7.1 & -1.565 & 0.984 & & 377656 & & & & \\
\hline 2000 & 871154.6 & 5 & 50.63 & 13.125 & 7.5 & 9.5 & -3.875 & 0.984 & 1.040 & 441066.6 & 117.5561 & 5.202 & 70.08658 & 47.46957 \\
\hline 2002 & 1044536 & 5 & 56.63 & 13.67 & 8 & 9.5 & -3.83 & 0.984 & 1.125 & 591569.1 & & 5.624 & & \\
\hline 2003 & 1143767 & 5 & 59.47 & 13.67 & 8 & 9.5 & -3.83 & 0.984 & 1.170 & 680147 & & 5.848 & & \\
\hline 2006 & 1501689 & 5 & 67.32 & 13.67 & 8 & 9.5 & -3.83 & 0.984 & 1.315 & 1010999 & & 6.575 & & \\
\hline 2007 & 1644349 & 5 & 69.75 & 13.67 & 8 & 9.5 & -3.83 & 0.984 & 1.367 & 1146861 & & 6.837 & & \\
\hline 2008 & 1800562 & 5 & 72.07 & 13.67 & 8 & 9.5 & -3.83 & 0.984 & 1.422 & 1297744 & & 7.109 & & \\
\hline 2009 & 1971616 & 5 & 74.31 & 13.67 & 8 & 9.5 & -3.83 & 0.984 & 1.478 & 1465185 & 124.5 & 7.392 & & \\
\hline
\end{tabular}


Table 3

\section{Scenario 2}

\begin{tabular}{|c|c|c|c|c|c|c|c|c|c|c|c|c|c|c|}
\hline Year & GDP & $\begin{array}{l}\text { Def/ } \\
\text { GDP }\end{array}$ & $\begin{array}{l}\text { Debt// } \\
\text { GDP }\end{array}$ & $\begin{array}{l}\text { LT } \\
\text { rate }\end{array}$ & CPI & nu & rho & 1+rho & delta & debt & Delta*b & Delta*d $^{*}$ & $\begin{array}{c}\text { Sum- } \\
\text { delta*d }^{*}\end{array}$ & bt \\
\hline 2000 & 871154.6 & -1 & 45.48 & 11.93 & 6 & 9.5 & -3.572 & 0.986 & 1.037 & 396186.1 & 34.42651 & -1.037 & -13.7735 & 48.2 \\
\hline 2002 & 1044536 & -1 & 40.32 & 11.93 & 6 & 9.5 & -3.572 & 0.986 & 1.115 & 421188.5 & & -1.115 & & \\
\hline 2003 & 1143767 & -1 & 37.88 & 11.93 & 6 & 9.5 & -3.572 & 0.986 & 1.157 & 433289.5 & & -1.157 & & \\
\hline 2005 & 1371405 & -1 & 33.26 & 11.93 & 6 & 9.5 & -3.572 & 0.986 & 1.244 & 456134.3 & & -1.244 & & \\
\hline 2006 & 1501689 & -1 & 31.07 & 11.93 & 6 & 9.5 & -3.572 & 0.986 & 1.290 & 466609 & & -1.290 & & \\
\hline 2007 & 1644349 & -1 & 28.96 & 11.93 & 6 & 9.5 & -3.572 & 0.986 & 1.338 & 476242.5 & & -1.338 & & \\
\hline 2008 & 1800562 & -1 & 26.93 & 11.93 & 6 & 9.5 & -3.572 & 0.986 & 1.387 & 484852.2 & & -1.387 & & \\
\hline 2009 & 1971616 & -1 & 24.97 & 11.93 & 6 & 9.5 & -3.572 & 0.986 & 1.439 & 492232.6 & 124.5 & -1.439 & & \\
\hline
\end{tabular}




\section{Table 4}

\section{Scenario 3}

\begin{tabular}{|c|c|c|c|c|c|c|c|c|c|c|c|c|c|c|}
\hline Year & GDP & $\begin{array}{l}\text { Def/ } \\
\text { GDP }\end{array}$ & $\begin{array}{l}\text { Debt/ } \\
\text { GDP }\end{array}$ & LT rate & CPI & nu & rho & $1+$ rho & delta & debt & Delta*b & Delta* $^{*}$ & $\begin{array}{c}\text { Sum } \\
\text { delta*d }^{*}\end{array}$ & bt \\
\hline 1999 & 795575 & 1.5 & 48.2 & 12.34 & 6.5 & 7.2 & -1.357 & 0.986 & & 377656 & & & & \\
\hline 2000 & 871154.6 & 1.5 & 47.98 & 11.93 & 6 & 9.5 & -3.572 & 0.986 & 1.037 & 417965 & 68.86023 & 1.556 & 20.66023 & 48.2 \\
\hline 2001 & 953914.3 & 1.5 & 47.76 & 11.93 & 6 & 9.5 & -3.572 & 0.986 & 1.075 & 455632.1 & & 1.613 & & \\
\hline 2002 & 1044536 & 1.5 & 47.56 & 11.93 & 6 & 9.5 & -3.572 & 0.986 & 1.115 & 496763.7 & & 1.673 & & \\
\hline 2003 & 1143767 & 1.5 & 47.36 & 11.93 & 6 & 9.5 & -3.572 & 0.986 & 1.157 & 541682.4 & & 1.735 & & \\
\hline 2004 & 1252425 & 1.5 & 47.17 & 11.93 & 6 & 9.5 & -3.572 & 0.986 & 1.199 & 590741.4 & & 1.799 & & \\
\hline 2005 & 1371405 & 1.5 & 46.98 & 11.93 & 6 & 9.5 & -3.572 & 0.986 & 1.244 & 644326.7 & & 1.866 & & \\
\hline 2006 & 1501689 & 1.5 & 46.80 & 11.93 & 6 & 9.5 & -3.572 & 0.986 & 1.290 & 702861 & & 1.935 & & \\
\hline 2007 & 1644349 & 1.5 & 46.63 & 11.93 & 6 & 9.5 & -3.572 & 0.986 & 1.338 & 766806.5 & & 2.007 & & \\
\hline 2008 & 1800562 & 1.5 & 46.47 & 11.93 & 6 & 9.5 & -3.572 & 0.986 & 1.387 & 836668.8 & & 2.081 & & \\
\hline 2009 & 1971616 & 1.5 & 46.31 & 11.93 & 6 & 9.5 & -3.572 & 0.986 & 1.439 & 913001.2 & 124.5 & 2.158 & & \\
\hline 2010 & 2158919 & 1.5 & 46.15 & 11.93 & 6 & 9.5 & -3.572 & 0.986 & 1.492 & 996409.1 & 128.5 & 2.238 & & \\
\hline
\end{tabular}




\section{REFERENCES}

- $\quad$ Abedian, I. \& Biggs, M. (ed.) 1998. Economic Globalization and Fiscal Policy. Cape Town: Oxford University Press.

- $\quad$ Agénor, P.R. \& Montiel, P.J. 1999. Development Macroeconomics. $\left(2^{\text {nd }}\right.$ edition) Princeton, New Jersey: Princeton University Press.

- Biggs, M. 1996. "Does South Africa's Government Debt Threaten the Sustainability of Fiscal Policy" Unpublished dissertation, University of Cape Town, Cape Town.

- $\quad$ Blejer, M.I. \& Cheasty, A. 1990. Analytical and Methodological Issues in the Measurement of Fiscal Deficits. IMF Working Papers (November): 1-61.

- $\quad$ Blejer, M.I. \& Cheasty, A. (ed.) 1993. How to Measure the Fiscal Deficit: Analytical and Methodological Issues. Washington, D.C.: International Monetary Fund.

- $\quad$ Easterly, W.R., Rodríguez, C. A. \& Schmidt-Hebbel, K. (ed.) 1994. Public Sector Deficits and Macroeconomic Performance. Washington, D.C.: Oxford University Press.

- Eisner, R. 1989. Budget Deficits: Rhetoric and Reality. Journal of Economic Perspectives 3: 73-93.

- $\quad$ Hakkio, C.S. \& Rush, M. 1991. Is the Budget Deficit "Too Large"? Economic Inquiry 29 (3): 429-445.

- Heller, P.S., Haas, R.D. \& Mansur, A.S. 1986. A Review of the Fiscal Impulse Measure. IMF Occasional Papers (May): 1-43.

- Jacobs, D.F. 2000. Die Begrotingstekort: Meting en Implikasies. Unpublished doctoral thesis, University of Pretoria, Pretoria.

- Republic of South Africa. 1996. Growth, Employment and Redistribution Strategy. Pretoria: Ministry of Finance.

- Rocha, R de R. \& Saldanha, F. 1992. Fiscal and Quasi-Fiscal Deficits, Nominal and Real: Measurement and Policy Issues. World Bank Policy Research Working Papers (June): 1 - 59.

- Tanzi, V., Blejer, M.I. \& Teijeiro, M.O. 1988. The Effects of Inflation on the Measurement of Fiscal Deficits. IMF Occasional Papers 59: 1 - 70. 